\title{
ANALYSIS ON SHUTTLE BUS STOP SERVICE PERFORMANCE BASED ON THE USER'S PERCEPTION. THE CASE STUDY OF TRANS BINTARO, SOUTH TANGERANG (INDONESIA)
}

\author{
Fredy Jhon Philip SITORUS ${ }^{1,}$ Eka PERMANASARI ${ }^{2}$
}

DOI: 10.21163/GT_2019. 141.32

\begin{abstract}
:
Shuttle bus is one of the mass transportation modes serving passengers from one point to another in a fast and accurate time. As passengers move from one point to another, a shuttle bus stop is considered to be an important factor which determines customer's satisfaction and needs. This study investigates the service performance of Trans Bintaro shuttle bus stop in South Tangerang based on the users' perception. Using qualitative method, performance is investigated based on the Importance Performance Analysis (IPA), and the customer satisfaction is measured based on the Customer Satisfaction Index (CSI). Data are collected through distributing questionnaires to shuttle bus customers to get their perception about the service performance. The study shows that only few quality service aspects such as safety, accessibility, and security of the bus stop are considered important, yet currently provide low service level. Based on the customer satisfaction analysis, accessibility to information plays crucial role at the shuttle bus stop. On the other hand, respondents see other aspects such as sitting and smoking areas are not crucial in determining customer satisfaction. These findings provide feedback to Bintaro Jaya Town Management in improving the service performance.
\end{abstract}

Key-words: Bus Stop, Importance, Customer Satisfaction, Shuttle Bus Service.

\section{INTRODUCTION}

The impact of this rapid urbanization is the decreasing land for residential. In Jakarta case, the surrounding area of Bekasi, Depok, Tangerang and Bogor have become new suburbia, where people live yet work in the city. High level commuting from these surrounding cities to Jakarta becomes a necessary. However, these suburbs lack of public transport system. People are pushed to use private cars and motorcycles, which caused huge traffic congesting on the road. Although Jakarta is developing its public transportation network lately, private sector plays crucial roles in providing public transportation which links the new suburb to the city. In this case, the new suburb becomes new trip generation point which needs to be linked to the economic center as the trip attraction.

This paper analyzes the rapid development and the service level of Trans Bintaro shelter in Bintaro, South Tangerang based on user's perception. The development of Bintaro as the new suburb grows rapidly for the past 10 years. The number of landed houses and apartments has been increased steadily, which indicates the growing number of inhabitant living in this new town. Providing public transportation service in the residential area has several purposes: providing reasonable transportation cost and reducing traffic; overcoming parking space scarcity; eliminating road accidents; and enhancing air quality by reducing pollution. However, not all shuttle bus providers can achieve those purposes,

\footnotetext{
${ }^{1}$ Universitas Pembangunan Jaya, Civil Engineering, Indonesia, fredy.jhon@upj.ac.id;

${ }^{2}$ Universitas Pembangunan Jaya, Indonesia, Eka.permanasari@upj.ac.id.
} 
mainly due to user-unfriendly transit system, insufficient funding, low service quality and transit cost related.

Public transportation services in Jakarta, in particular bus service, are commonly below the standard. Meanwhile, social impact of motorization could extend to rural communities as well as urban cities. With expanding road capacity, car owners and users travel longer distances away from the city, causing an increase in new transport demand (Schipper and $\mathrm{Ng}, 2005)$. Increasing the service quality of public transportation should be the major concern of government and private sectors to make sustainable cities.

Service quality and customer satisfaction are two very closely related, customer satisfaction is generally a key factor in assessing the quality of a service (Kavaliauskiene et.al 2014). In transportation industry, there is a fact that both of service quality and customer satisfaction are recognized as major factors in successful business relationships ((Jayawardhena 2010), including labour mobility (Vilem Paril et al., 2015). One of the strategies in providing service quality is by having proper shuttle bus stop for customers. Therefore, the aim of this research is to investigate service quality of a shuttle bus stop based on the customers' interest and expectation. The outcome of the research can be used for transport provider to enhance the service quality and ensure the availability of important aspects required in shuttle bus stop.

\section{STUDY AREA AND DATA}

Bintaro Jaya is an area of 2,000 hectares located in the city of South Tangerang (Indonesia) which was built as a residential and commercial area and is supported by educational, recreational, health services and transportation networks that are integrated and connected with Jabodetabek, one of which is the Trans shuttle bus service Bintaro.

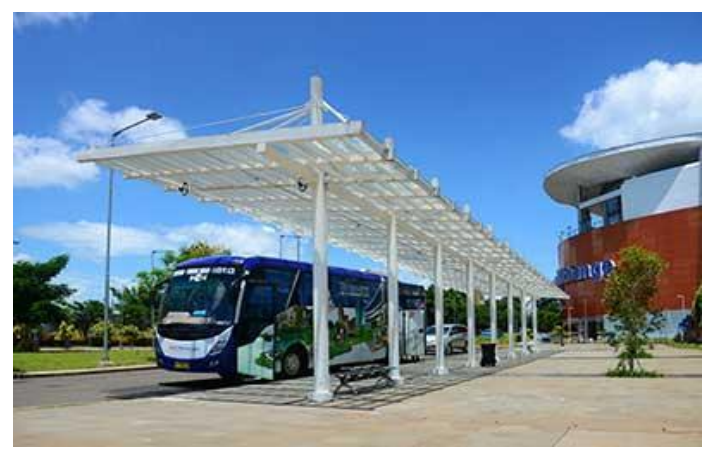

Fig. 1. Trans Bintaro shelter in Bintaro, South Tangerang.

Public transportation service must have minimum service standard that includes type and quality of service. According to regulation of Ministry of Transportation of Indonesia Number 10, year 2012, concerning Minimum Service Standard of public Transportation based on road, the type of services, which referred to is security, safety, comfort, affordability, equality, and regularity. While the quality of service is an indicator, the value size or amount is used by operator in implementing the governance of public transport services. On the other hand, one important component in road-based public transport system is the availability of bus stop. 
To increase public transport usage, the service should be designed in a way that accommodates the levels of service required by customers (Beirao \& Cabral, 2007). In some literature, aspect of reliability, frequency, travel time, and ticketing (Hensher et al., 2007; Tyrinopoulos \& Aifadopoulou, 2008), comfortable and cleanliness (Eboli \& Mazzulla, 2007), network coverage/distance to stop (Eriksson et.al. 2008; Tyrinopoulos et.al 2008) and safety issue (Fellesson \& Friman 2008) are all known to be important factors in customer evaluations of public transport service quality.

\section{METHODOLOGY}

\subsection{Data for Analysis}

Respondent data are gathered through dispersing questionnaires to get customer's insights on service quality, and important aspects required in shuttle bus stop. The questionnaire form outlines formal questions to get the information of the quality service through value judgment using Likert scale, which is a widely used rating scale. It requires that the respondents to indicate a degree of agreement or disagreement with each of a series of statements about the stimulus object (Malhotra \& Birks, 2007). Sampling is applied through questioning the Trans Bintaro users by using Slovin formula

\subsection{Statistic Method}

The questionnaire results will be tested, including its validity and reliability to get a significant accuracy. One questionnaire is considered valid if the question can reveal something which can be measured by the question itself. To test the accuracy, an item will be validated through the correlation with the whole items. Testing is used through applying Product Moment Pearson correlation in 5\% significant level. The reliability is tested through Alpha Cronbach's method to get alpha's value based on the analysis.

The correlation between age and gender with the answer related to the user's interest and expectation is done through non-parametric statistic method of Chi square comparative analysis. Statistic non-parametric analysis of Wilcoxon Signed Rank Test is used to compare different questionnaire results on user's interest and expectation on quality aspects to be provided in shuttle bus service. These analysis methods are applied to test the different models given to the research object, by considering direction and different relative magnitude from the two adjoining samples.

\subsection{Importance Performance Analysis}

The Importance Performance Analysis (IPA) method is applied to determine the relationship between the customer and the priority of product/service quality enhancement through quadrant analysis. Apart from that, this method explains the analyzed variables and easily identifies the weak variable to be followed up by the management. To increase the customer satisfaction, IPA method is applied to explore the attributes that have to be enhanced (Silva \& Fernandes, 2011)

\section{RESULTS AND DISCUSSIONS}

\subsection{Validation and Reliability Test}

From the validation analysis on Table 1, each question is confirmed as valid where all questions on satisfaction and necessity give the $r_{\text {count }}$ with significant $\langle=0.01$, more than the $\mathrm{r}_{\text {table }}$ of 0.128 . After all the questions are validated, then reliability test is needed to find out the questionnaire consistency in this research. Decision on this test is based on the Alpha 


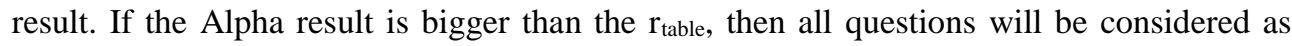
consistent and reliable. Alpha score is 0.666 , it shows that all aspects of questions have consistency and reliability between $0.6-0.7$.

\subsection{Importance Level Description}

The data analysis shows that majority of respondents give answers of "very important" and "important" with the highest portion on attributes of roof, accessibility, safety, onsite service and security. The highest point is on roof aspect $(95.4 \%)$, and the lowest point is on smoking area $(73.9 \%)$.

Table 1. Questionnaires Validation test result with Pearson Product Moment.

\begin{tabular}{|c|c|c|c|c|c|}
\hline \multirow[b]{2}{*}{ No } & \multirow[b]{2}{*}{ Aspects on Shuttle bus stop } & \multicolumn{2}{|c|}{$\mathbf{r}_{\text {count }}$} & \multicolumn{2}{|l|}{$\mathbf{r}_{\text {table }}$} \\
\hline & & $\begin{array}{c}\text { Importance } \\
\text { level }\end{array}$ & $\begin{array}{c}\text { Satisfaction } \\
\text { level }\end{array}$ & & \\
\hline 1 & Accessibility & 0.542 & 0.347 & 0.128 & Valid \\
\hline 2 & Roof & 0.623 & 0.407 & 0.128 & Valid \\
\hline 3 & Quality and numbers of seat & 0.638 & 0.516 & 0.128 & Valid \\
\hline 4 & Lighting & 0.652 & 0.441 & 0.128 & Valid \\
\hline 5 & Bus steps & 0.592 & 0.490 & 0.128 & Valid \\
\hline 6 & Smoking Area & 0.443 & 0.431 & 0.128 & Valid \\
\hline 7 & Supporting facilities & 0.569 & 0.536 & 0.128 & Valid \\
\hline 8 & Cleanliness & 0.666 & 0.387 & 0.128 & Valid \\
\hline 9 & Information & 0.628 & 0.471 & 0.128 & Valid \\
\hline 10 & Safety & 0.659 & 0.369 & 0.128 & Valid \\
\hline 11 & Security & 0.692 & 0.435 & 0.128 & Valid \\
\hline 12 & Onsite Service & 0.681 & 0.461 & 0.128 & Valid \\
\hline
\end{tabular}

After this importance level description, the next step is determining whether there is significant difference between necessity level on group of questions and the Kruskal Wallis test. The hypothesis of this test is as followed:

$\mathrm{H}_{0} \quad$ : Respondent feedback on every quality aspect of the shuttle bus stop is the same.

$\mathrm{H}_{1} \quad$ : At least one aspect of the shuttle bus stop service has different feedback

From analysis of Kruskal Wallis, the null hypothesis $\left(\mathrm{H}_{0}\right)$ is rejected and $\mathrm{H}_{1}$ is accepted which means that at least one quality aspect of the bus stop which has different value. This condition can be explained from Asymp.Sig. Number of 0.000 less than $\langle=0.05$ and ChiSquare value of 107.226 which is more that the chi-square table value of 19.675 .

Crosstab classification analysis is applied to investigate the correlation between the age and the answer of the respondents based on the necessity level. This crosstab is one of the correlation analyses to overview the connection among the variables (minimum of two variables) with categories of nominal or ordinal [12]. The hypotheses used are as followed:

$\mathrm{H}_{0} \quad$ : Gender and the respondents' answers for the needs level are not correlated.

$\mathrm{H}_{1} \quad$ : Gender and the respondents' answers for the needs level are correlated. 
Table 2 shows that the $\mathrm{p}$ value is higher that the significant $\langle=0.05$ which therefore the null hypothesis (H0) can be accepted. Thus, it can be concluded that the gender issue does not influence the answer for all needs level.

Table 2. Cross-classification of respondents based on gender in accordance to the Needs Level.

\begin{tabular}{|c|c|c|c|c|c|c|c|c|}
\hline \multirow{2}{*}{ No } & \multirow{2}{*}{ Aspects } & \multirow{2}{*}{ Gender } & \multicolumn{4}{|c|}{ Importance Level (\%) } & \multirow{2}{*}{$\begin{array}{c}\mathrm{P} \\
\text { value }\end{array}$} & \multirow{2}{*}{$\mathrm{H}_{0}$} \\
\hline & & & 1 & 2 & 3 & 4 & & \\
\hline \multirow[t]{2}{*}{1} & Accessibility & $\operatorname{man}$ & 18.27 & 27.41 & 2.72 & 0.25 & \multirow{2}{*}{0.190} & \multirow{2}{*}{ accepted } \\
\hline & & woman & 25.19 & 23.70 & 1.98 & 0.49 & & \\
\hline \multirow[t]{2}{*}{2} & Roof & $\operatorname{man}$ & 20.49 & 25.68 & 2.22 & 0.25 & \multirow{2}{*}{0.055} & \multirow{2}{*}{ accepted } \\
\hline & & woman & 27.16 & 21.98 & 1.23 & 0.99 & & \\
\hline \multirow[t]{2}{*}{3} & Quality and numbers & man & 17.78 & 25.93 & 4.20 & 0.74 & \multirow{2}{*}{0.126} & \multirow{2}{*}{ accepted } \\
\hline & & woman & 18.27 & 30.86 & 1.98 & 0.25 & & \\
\hline \multirow[t]{2}{*}{4} & Lighting & man & 18.27 & 25.19 & 4.69 & 0.49 & \multirow{2}{*}{0.281} & \multirow{2}{*}{ accepted } \\
\hline & & woman & 17.53 & 30.62 & 2.96 & 0.25 & & \\
\hline \multirow[t]{2}{*}{5} & Bus steps & $\operatorname{man}$ & 17.04 & 27.16 & 3.95 & 0.49 & \multirow{2}{*}{0.540} & \multirow{2}{*}{ accepted } \\
\hline & & woman & 20.00 & 28.40 & 2.47 & 0.49 & & \\
\hline \multirow[t]{2}{*}{6} & Smoking Area & $\operatorname{man}$ & 15.31 & 20.25 & 9.88 & 3.21 & \multirow{2}{*}{0.348} & \multirow{2}{*}{ accepted } \\
\hline & & woman & 19.26 & 19.01 & 8.40 & 4.69 & & \\
\hline \multirow[t]{2}{*}{7} & Supporting facilities & $\operatorname{man}$ & 17.78 & 24.44 & 5.19 & 1.23 & \multirow{2}{*}{0.599} & \multirow{2}{*}{ accepted } \\
\hline & & woman & 20.49 & 25.43 & 4.94 & 0.49 & & \\
\hline \multirow[t]{2}{*}{8} & Cleanliness & man & 19.26 & 19.01 & 8.40 & 4.69 & \multirow{2}{*}{0.317} & \multirow{2}{*}{ accepted } \\
\hline & & woman & 23.46 & 24.44 & 3.46 & 0.00 & & \\
\hline \multirow[t]{2}{*}{9} & Information & man & 20.74 & 22.47 & 4.69 & 0.74 & \multirow{2}{*}{0.071} & \\
\hline & & woman & 20.99 & 27.65 & 2.72 & 0.00 & & accepted \\
\hline 10 & Safety & man & 20.99 & 23.70 & 2.96 & 0.99 & 0141 & \\
\hline & & woman & 26.91 & 22.22 & 1.98 & 0.25 & 0.141 & accepted \\
\hline 11 & Security & man & 25.68 & 18.27 & 3.95 & 0.74 & 0118 & \\
\hline & & woman & 30.37 & 19.01 & 1.73 & 0.25 & 0.118 & accepted \\
\hline 12 & Onsite Service & $\operatorname{man}$ & 20.49 & 24.69 & 2.22 & 1.23 & & \\
\hline & & woman & 24.69 & 23.95 & 1.98 & 0.74 & 0.596 & accepted \\
\hline
\end{tabular}

Note: 1 = Very Importance, 2 = moderately importance, $3=$ slightly importance, $4=$ low importance

\subsection{Satisfaction Level Description}

Majority of the answers stated "very satisfied' and 'satisfied' with the highest point on the questions about accessibility, safety, security and on site staff service. Meanwhile, the lowest point applies to supporting facilities, smoking area, information, numbers of seats and accessible stairs. The highest value applies to accessibility (87.4\%) and the lowest value applies to supporting facilities around the bus shelter $(73.9 \%)$.

To decide whether there is a significant difference in statistics between the satisfaction levels on the questions using Kruskal Wallis test. The hypothesis in this test is as followed:

$\mathrm{H}_{0} \quad$ : The result on every quality aspect on the bus stop is the same.

$\mathrm{H}_{1} \quad$ : At least one aspect on the bus stop has a different result.

The Kruskal Wallis analysis shows that both the null hypothesis (H0) and the H1 are rejected. It indicates that at least one quality aspect has a different setting value. This can be 
explained from the Asymp.Sig value of 0.000 which less than $\langle=0.05$ and Chi-Square value of 204.167 which is more than the Chi-Square table of 19.675 .

Table 3. Cross-classification on Gender Respondents on the Satisfaction Level.

\begin{tabular}{|c|c|c|c|c|c|c|c|c|}
\hline \multirow{2}{*}{ No } & \multirow{2}{*}{ Aspects } & \multirow{2}{*}{ Gender } & \multicolumn{4}{|c|}{ Satisfaction Level (\%) } & \multirow{2}{*}{$P$ value } & \multirow{2}{*}{$\mathrm{H}_{0}$} \\
\hline & & & 1 & 2 & 3 & 4 & & \\
\hline \multirow[t]{2}{*}{1} & Accessibility & $\operatorname{man}$ & 11.60 & 29.88 & 6.42 & 0.74 & \multirow{2}{*}{0.247} & \multirow{2}{*}{ Accepted } \\
\hline & & woman & 9.88 & 36.05 & 5.19 & 0.25 & & \\
\hline \multirow[t]{2}{*}{2} & Roof & man & 12.84 & 28.40 & 7.16 & 0.25 & \multirow{2}{*}{0.347} & \multirow{2}{*}{ Accepted } \\
\hline & & woman & 11.36 & 31.11 & 7.65 & 1.23 & & \\
\hline \multirow[t]{2}{*}{3} & Quality and numbers of & $\operatorname{man}$ & 10.37 & 28.64 & 9.38 & 0.25 & \multirow{2}{*}{0.102} & \multirow{2}{*}{ Accepted } \\
\hline & & woman & 6.91 & 34.07 & 9.38 & 0.99 & & \\
\hline \multirow[t]{2}{*}{4} & Lighting & $\operatorname{man}$ & 11.60 & 29.38 & 7.65 & 0.00 & \multirow{2}{*}{0.247} & \multirow{2}{*}{ Accepted } \\
\hline & & woman & 8.40 & 34.57 & 8.15 & 0.25 & & \\
\hline \multirow[t]{2}{*}{5} & Bus steps & man & 10.12 & 29.63 & 7.90 & 0.99 & \multirow{2}{*}{0.582} & \multirow{2}{*}{ Accepted } \\
\hline & & woman & 8.15 & 33.33 & 9.14 & 0.74 & & \\
\hline \multirow[t]{2}{*}{6} & Smoking Area & $\operatorname{man}$ & 10.86 & 19.51 & 14.07 & 4.20 & \multirow{2}{*}{0.005} & \multirow{2}{*}{ Rejected } \\
\hline & & woman & 5.19 & 23.46 & 15.56 & 7.16 & & \\
\hline \multirow[t]{2}{*}{7} & Supporting Facilities & $\operatorname{man}$ & 8.64 & 21.98 & 13.58 & 4.44 & \multirow{2}{*}{0.299} & \multirow{2}{*}{ Accepted } \\
\hline & & woman & 6.67 & 21.23 & 17.78 & 5.68 & & \\
\hline \multirow[t]{2}{*}{8} & Cleanliness & $\operatorname{man}$ & 12.35 & 29.88 & 5.93 & 0.49 & \multirow{2}{*}{0.594} & \multirow{2}{*}{ Accepted } \\
\hline & & woman & 10.62 & 32.10 & 7.90 & 0.74 & & \\
\hline \multirow[t]{2}{*}{9} & Information & $\operatorname{man}$ & 8.40 & 29.63 & 9.14 & 1.48 & \multirow{2}{*}{0.901} & Accented \\
\hline & & woman & 10.12 & 30.12 & 9.88 & 1.23 & & Aсеертел \\
\hline 10 & Safety & man & 14.81 & 28.64 & 5.19 & 0.00 & 0013 & Reject \\
\hline & & woman & 9.14 & 33.58 & 8.40 & 0.25 & 0.013 & Rejected \\
\hline 11 & Security & $\operatorname{man}$ & 14.32 & 28.15 & 5.68 & 0.49 & 06 & Accented \\
\hline & & woman & 12.35 & 31.11 & 7.16 & 0.74 & 0.618 & Accepted \\
\hline 12 & Onsite service & $\operatorname{man}$ & 20.49 & 24.69 & 2.22 & 1.23 & 204 & Poistod \\
\hline & & woman & 24.69 & 23.95 & 1.98 & 0.74 & 0.042 & Rejected \\
\hline
\end{tabular}

On the cross-classification test to examine the influence of gender against the result on the satisfaction level, the hypothesis is as followed:

$\mathrm{H}_{0} \quad$ : Gender and the respondent's answers for the satisfaction level are not correlated.

$\mathrm{H}_{1} \quad$ : Gender and the respondent's answers for the satisfaction level are correlated.

The analysis on Table 3 explains that there is a gender influence on the satisfaction level for the elements of on-site staff service, smoking area and safety showing through pvalue less than the significant $(\langle)=0.05$. This is due to the smoking users are mostly men, and on the aspects of safety, mostly men are easily move around. On the other aspects, pvalue is bigger than 0.05 , which in turns shows the satisfaction level is not determined based on the gender.

In order to find out the comparison between satisfaction level and importance level, therefore, Wilcoxon Signed Rank test is applied. The Wilcoxon test is part of the nonparametric test used to compare between two groups, which are related. And to investigate whether there is a median difference from the paired observation, which 
calculates the differences between two observations of necessity and satisfaction. The significant level used is $\langle=0.05$ with the hypothesis are used as follows:

$\mathrm{H}_{0} \quad$ : Frequency distribution relation between satisfaction and importance level is identical.

$\mathrm{H}_{1} \quad$ : Frequency distribution relation between satisfaction and importance level is not identical

Table 4 shows that $\mathrm{p}$-value is less than the significant $\langle=0.05$ which therefore hypothesis $\mathrm{HO}$ is rejected. This implies that frequency relative variable on the necessity level and satisfaction level is not identical. This also explains that the high result of importance level does not necessarily resulted high satisfaction level.

Table 4. The Wilcoxon Signed Rank Test Result.

\begin{tabular}{clccccc}
\hline No & \multicolumn{1}{c}{ Aspects } & $\begin{array}{c}\text { Mean } \\
\text { rank }\end{array}$ & $\begin{array}{c}\text { Total } \\
\text { rank }\end{array}$ & Z & P value & hypothesis \\
\hline 1 & Accessibility & 106.21 & 5735.5 & -6.560 & 0.000 & $\mathrm{H}_{0}$ rejected \\
2 & Roof & 99.92 & 4996.0 & -7.422 & 0.000 & $\mathrm{H}_{0}$ rejected \\
3 & Quality and numbers of seat & 100.77 & 4837.0 & -7.084 & 0.000 & $\mathrm{H}_{0}$ rejected \\
4 & Lighting & 98.73 & 5430.0 & -5.265 & 0.000 & $\mathrm{H}_{0}$ rejected \\
5 & Bus Steps & 101.85 & 5501.0 & -6.438 & 0.000 & $\mathrm{H}_{0}$ rejected \\
6 & Smoking Area & 113.85 & 9222.0 & -5.510 & 0.000 & $\mathrm{H}_{0}$ rejected \\
7 & Supporting Facilities & 95.49 & 4583.5 & -9.542 & 0.000 & $\mathrm{H}_{0}$ rejected \\
8 & Cleanliness & 98.82 & 5040.0 & -6.166 & 0.000 & $\mathrm{H}_{0}$ rejected \\
9 & Information & 94.55 & 4349.5 & -7.981 & 0.000 & $\mathrm{H}_{0}$ rejected \\
10 & Safety & 115.71 & 6711.0 & -6.486 & 0.000 & $\mathrm{H}_{0}$ rejected \\
11 & Security & 109.54 & 5148.5 & -8.213 & 0.000 & $\mathrm{H}_{0}$ rejected \\
12 & Onsite Service & 106.93 & 6415.5 & -5.967 & 0.000 & $\mathrm{H}_{0}$ rejected \\
\hline
\end{tabular}

\subsection{Importance Performance Analysis}

This research uses Importance Performance Analysis (IPA) method to measure the relationship between the customer's perception and the decision to enhance the quality as known as the quadrant analysis. Apart from that, this method is also to investigate variables to be improved by the management to meet the customers' needs.

The quadrant analysis in Figure 2 explains a few things:

a) Quadrant 1 (High priority)

Factors in this area should be closely examined and become the forts priority to enhance the service level. This quadrant shows that the information aspect in the bus stop as the high priority to be delivered.

b) Quadrant 2 (Maintenance Service Level)

Aspects shown in this quadrant are considered as important and already provide good quality service. The aspects are include accessibility, roof, cleanliness, and safety.

c) Quadrant 3 (Low Priority)

Aspects shown in this quadrant are considered as having low necessity and satisfaction, which does not require enhancement. The aspects are the quality, and the numbers of seat, smoking area, and supporting facilities

d) Quadrant 4 (Over Service) 
In this quadrant there are aspects considered not really important. Therefore, the management can focus on other aspects categorized as the high priority that require enhancement. The aspects are followed: lighting and bus steps

The measurement of customer satisfaction is needed to examine how much expectation the Bintaro Jaya management can deliver in relation to the bust stop service. The Customer Satisfaction Index (CSI) method uses the median point to examine the importance and satisfaction levels on every aspect.

Based on this measurement, the CSI index is $75.33 \%$. This CSI index is gathered from dividing the total score of the Weight Score with the maximum scale in this research (i.e. 5), then multiplying it with $100 \%$. From this CSI score, the service level of the bus stop is categorized as borderline, which means that the management of Trans Bintaro should do enhancement to ensure the good service level that meets the customer satisfaction based on the IPA quadrant analysis.

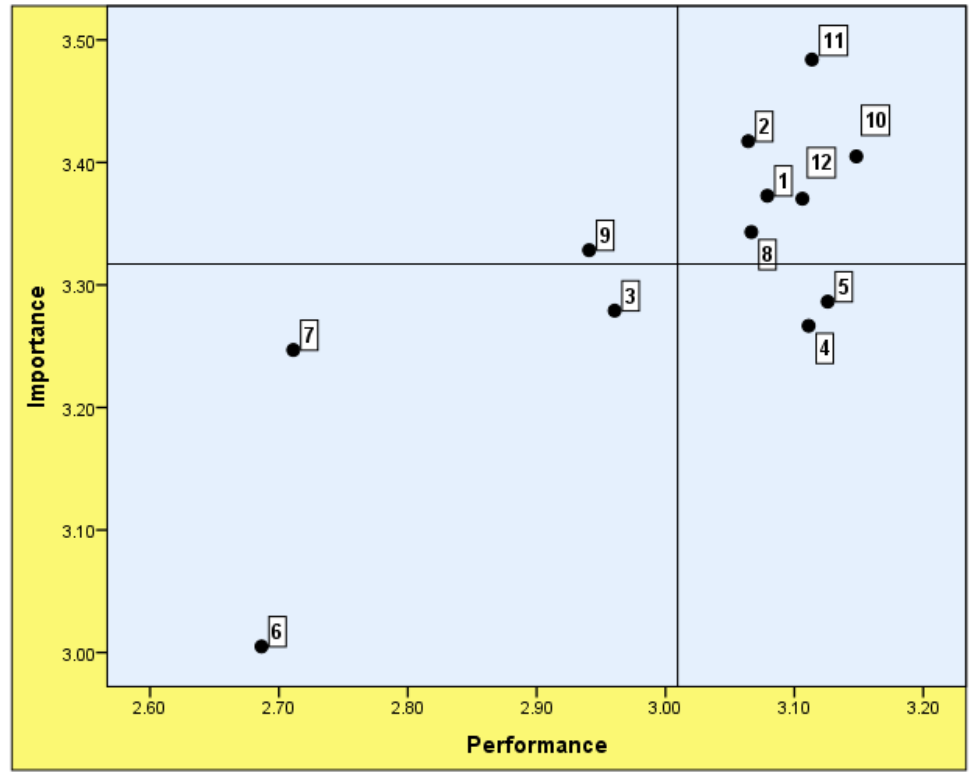

Fig. 2. Quadrant Analysis.

\section{CONCLUSIONS}

In public transportation system, providing shuttle bus stop is considered as an important factor. The transportation service provider should facilitates the needs of customers to ensure the best service. This study shows that a few aspects on quality service are still in the poor performance, such as the roof, accessibility, ground-staff service, and security. From the analysis of survey based on the gender, the ground-staff service, smoking area, and safety are the three factors that need to be improved. From the Importance Satisfaction Performance analysis, the information provisions holds a key point for ensuring the customer satisfaction, whereas seating, smoking area, and other facilities are not considered as important. Further research should be conducted to determine the effect on the level of customer loyalty. 


\section{REFERENCES}

Beirao, G. \& Cabral, J. A. S. (2007) Understanding attitudes towards public transport and private car: A qualitative study. Transport Policy, 14(6), $478-489$.

Eboli, L. \& Mazzulla, G. (2007) Service quality attributes affecting customer satisfaction for bus transit. Journal of Public Transportation ,10 (3), 21-34.

Eriksson, L., Friman M. \& Garling, T. (2008) Stated reason for reducing work - commute by car, Transportation Research Part F: Traffic Psychology and Behaviour, 11(6), 427-433.

Fellesson, M. \& Friman, M. (2008) Perceived satisfaction with public transport service in nine European cities. Journal of the Transportation Research Forum, 47(3), 93-103.

Hensher, D. A., Stopher, P. \& Bullock, P. (2003) Service Quality - Developing a service quality index in the provision of commercial bus contracts. Transport Research Part A: Policy and Practice, 37(6), 499-517.

Jayawardhena, Ch. (2010) The impact of service encounter quality in service evaluation: evidence from a business-to-business context. Journal of Business \& Industrial Marketing, 25 (5), 338348.

Kavaliauskiene, I.M., Aranskis, A. \& Litvinenko, M. (2014) Consumer satisfaction with the quality of logistics services. Procedia-Social and Behavioral Sciences, 110 924), 330-340.

Malhotra, N. K., \& Birks, D. F. (2007) Marketing Research an Applied Approach, 3rd edition, Pearson Prentice Hall, 348-349.

Martilla, J. A. \& James, J. C. (1977). Importance performance analysis. Journal of Marketing ,41(1), 77-79.

Paril, V., Kunc, J., Sasinka, P., Tonev, P. \& Viturka, M. (2015) Agglomeration effects of the Brno City (Czech Republic) as exemplified by the population labour mobility. Geographia Technica $10(1), 66-76$.

Schipper, L. \& W.S. Ng. (2005) Rapid motorization in China: Environmental and social challenges. Background paper for Connecting East Asia. A new Frame work for Infrastructure.

Silva, F. H. \& Fernandes, P. O. (2011) Importance-performance analysis as a tool in evaluating higher education service quality: the empirical results of ESTiG (IPB). Creating Global Competitive Economies: A 360-Degree Approach, 306-315.

Tyrinopoulos, Y., \& Aifadopoulou, G. (2008) A complete methodology for quality control of passenger services in the public transport business. European Transport 38:1 - 16 (2008).

Tyrinopoulos, Y. \& Antoniou, C. (2008) Public transit user satisfaction: Variability and policy implications. Transport Policy, 15(4), 260-272. 